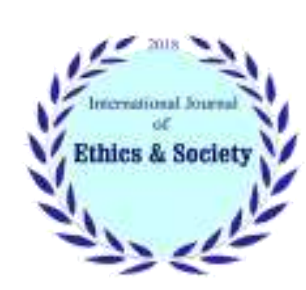

International Journal of Ethics \& Society (IJES)

Journal homepage: $\underline{\text { www.ijethics.com }}$

Vol. 2, No. $\mathbf{3 ( 2 0 2 0 )}$

(Original article)

\title{
Comparison of the Ethical Status of Public and Non-Profit Primary School Students
}

\author{
Parviz Nami, Hassan Pasha-Sharifi ${ }^{*}$, Malek Mirhashemi \\ Dept. of Psychology, Rudehen Branch, Islamic Azad University, Rudehen, Iran
}

\section{Abstract}

Background: The aim of this study was to compare the ethical status of public and non-profit elementary school students.

Method: The method of the present study was descriptive-correlational and in terms of purpose, it is an applied study. The statistical population of the whole elementary students of the second period (fourth to sixth grades) in Tehran in the academic year 2018-2019. 531 people were selected as the sample and the sampling method was stratified sampling. The research instrument was Moral Development Questionnaire. Data were analyzed through descriptive and inferential statistics by SPSS 24 software.

Results: Data analysis showed that there is a significant difference between the moral status of non-profit and public schools $(p<0.05)$. In other words, the average of moral status in non-profit schools is slightly higher. There was a significant difference between the moral status of boys' and girls' schools $(p<0.05)$. There was a significant difference between non-profit and public girls' schools $(p<0.05)$, but there was no significant difference between non-profit and public schools for boys $(p<0.05)$.

Conclusion: Based on the research findings, it can be said that non-profit schools have a better moral status than public schools.

Keywords: Ethics, Moral development, Public and non-profit schools, Elementary students

\section{Introduction}

School has long been considered as one of the most important influential factors in cultivating various educational, training and moral dimensions of the individual (1). In this regard, scholars such as Plato, Aristotle, Abu Ali Sina, Ghazali, Rousseau, Dewey, Froebel and other contemporary philosophers have emphasized the importance of the role of school in moral education and believed that schools cannot avoid dealing with the moral life of students (2). Proper education for moral development should be provided not only in the times related to moral education, but also in the times related to subjects and

* Corresponding Author: Email: hasan.pash.sharifi99@gmail.com

Received: 28 Nov 2020

Accepted: 30 Dec 2020 
special activities in line with its specific characteristics (3).

Ethics is a complex structure for which no single definition can easily be found. The behaviorist approach looks at values and ethics from the perspective of its external effects; because he considers moral change to be inherent (internal); therefore, values must also be viewed in terms of its external effects and its objective and physical aspects must be considered. The value explanation approach considers the role of the school to explain and specify values. The school should play an impartial role and explain and clarify values through games and classroom exercises. Researchers believe that explaining values and clarifying their scope and limits play a key role in teaching and learning (4).

By reviewing the theoretical studies of ethics, the main dimensions of ethics can be considered as follows: 1) Creative environment with global concerns such as human relationship with the environment, human understanding of responsibility towards the environment and commitment to conservation for generations It's about the future. Components such as environmental pollution, land use, food production and distribution, energy production and consumption, wildlife conservation, and species diversity are also within the scope of environmental ethics (5). 2) Social ethics; As a branch of Islamic ethics, it has faith in God and the dignity and dignity of the soul, which is stable and based on the teachings of bliss. It is desirable to achieve salvation in this world and the hereafter. The values and components discussed in social ethics include observing the rules and regulations of the school and society, dealing with offenders, students' relationship with others, adhering to and not circumventing the rules, and not taking a diagnostic look at the rules (6). 3) Self-care ethics; the highest form of care ethics can be seen in the relationship between mother and child. For this reason, the ethics of self-care is sometimes called maternal ethics or maternal thinking. Ethics of care has components such as moral attention, fair understanding, communication awareness, learning, response, healthy vitality and recreation, exercise, order and planning for the future, chastity, perseverance, appropriate reaction, etc. (7). 4) The ethics of family relations; the family is the most important social institution that has formed the sexual orientation of men and women and the emotional relations of parents to their children (8). In the ethics of family relations, the discussion of the type of family management, understanding the criteria governing the family, drawing goals, distributing maps, is related to ethics. The criteria by which family relationships are formed determine the type of relationship that governs the home and family. These criteria are the scales on which the moral weight of relationships between family members is based. 5) Human ethics; Human ethics is not goal-oriented, consequentialist or utilitarian, but task-oriented and his task is based on the virtue that man considers for himself in terms of "humanity" and "self-awareness of the value of humanity". Among the components considered in human ethics, we can mention free thinking, expression of feelings, fulfillment of the promise, truthfulness, honesty, observance of justice and fairness, moderation and non-discrimination between individuals (9). 6) Transcendent ethics: In addition to connecting to the highest level of virtues such as wisdom, chastity, courage and justice, transcendent morality in dealing with God's creation does not go beyond the framework of moral standards and in the face of other people's thoughts and criticism and evaluation of opinions. They do not exceed the red line of moral ethics. He considers himself responsible for the fate of others and is always meditating on doing the right thing and can make the most appropriate decision while controlling his emotions. Sustainability in helping others and selfsacrifice are other characteristics of transcendent ethics (10).

Moral development in children is very important and it is influenced by many groups and individuals. After the school family, they have a great impact on the moral education of children. The results of many studies indicate that teachers and school members and the school atmosphere in general are very effective in children's moral development (11). In this regard, the impact of public and non-profit schools is also controversial. Some label nonprofit schools as materialistic elitism. The same point is made in other researches (12 and 13). Of course, one researcher attributes this to the existence of

2

Available at: www.ijethics.com 
better teachers in private schools, because more salaries should be paid to teachers, still indirectly raise the same elitism (13). According to this view, nonprofit schools are thought to be useful for affluent groups who have the financial capacity to pay tuition (14).

Some believe that families choose non-profit schools to provide better education for their children. According to them, those who have a superior class position try to get better educational opportunities for their children. One of the results of the studies also indicates this point $(15,16)$. Others argue that the values and norms of public schools either do not adequately meet the needs of parents, or are fundamentally inconsistent with the values and norms of some families. For this reason, parents look for values and norms that are more in line with their and their children's views on the present and the future. In this sense, "social origin is one of the determinants of people's demand for non-profit education" (17). Normative pressure is also one of the factors in choosing non-profit schools (18). Normative pressure is seen in societies where people have retained their personal qualities and norms are general and pervasive and it causes certain actions of individuals that range from lifting nails to choice of clothes, home, school and so on. This view seems to be similar to other views in other parts of the world (17).

Although many studies have been conducted comparing the status of public and non-profit schools in terms of economic, social and educational impacts; But comparing the role of public and nonprofit schools in the development of ethics and moral education has created a research gap. In a study, researchers concluded that there is a significant relationship between gender, grade and degree and students' moral judgment $(19,20)$. One researcher concluded in a study that there is a significant difference between the moral judgment of girls and boys (21). Another study concluded that there is a correlation between the organizational climate of schools in the second and third grades and moral judgment (22). Another study found that there is a significant difference between the quality of schools in public and non-public schools and the conditions of girls' schools are more favorable, but in terms of school and student supervision, school health and general characteristics of principals, there is a significant difference between school groups. You do not exist (17). Researchers concluded in a study that there is a significant difference between the current situation and the desired situation of educational activities in non-profit schools (23). Researchers also concluded in a study that gender plays a significant role in different semantic and moral orientations, with women emphasizing emotional and care-oriented arguments and men emphasizing rational and justice-oriented tendencies (24). Other research results showed that in private schools, the moral development of students is better than religious (public) schools (25). What emerges from public and non-profit schools is that the state of educational quality, especially the state of morality in these two schools, is associated with both pros and cons. On the other hand, it should be said that scientific research on the moral status of students in these two types of schools is a research gap. In addition, monitoring the moral status in the elementary course is more important because their moral growth in this course can be stabilized and strengthened in the later stages of education. Therefore, to evaluate the subject of students' moral development, the present study is undeniable. The results of the research can be answers for the rate of moral growth in both types of schools and clearing up the ambiguities of some experts and families about the lack of attention to the growth of morality in public schools. Therefore, based on the above, the main purpose of this study is to compare the moral development of elementary students in the second year of Tehran in public and non-profit schools.

\section{Material and Methods}

The method of the present study was descriptivecorrelational and in terms of purpose, it is an applied study. The statistical population of all 22 elementary schools in Tehran in the academic year of 2018-2019 was 1765 schools (1179 public schools and 582 non-profit schools). Since the aim of the study was to compare ethics in public and non- 
profit elementary schools, stratified sampling method was used to select two types of public and non-profit schools and their gender and 531 students were selected as a statistical sample. In the sampling, first, the educational districts of Tehran are geographically divided into 5 central, northern, southern, western and eastern parts, and then 1 district from each district and 4 schools from each district, including 1 public boys 'school, 1 non-profit boys' school, 1 public girls 'school and 1 non-profit girls' school. 30 students from each school were selected in 3 educational levels. The sample size was also based on Krejcie and Morgan table.
The research tool was a questionnaire that had 6 dimensions (environmental, social, family relationships, human, transcendent and self-care) and 27 questions and based on a 6-part Likert scale from completely agree (6) to completely disagree (1). This questionnaire was prepared by Lotfabadi in 2005 and its reliability in the present study was 0.89 (Table 1). In order to ensure the correctness of the answer, 40 questionnaires were first distributed, the analysis of which showed that the comprehension and questions were easy. However, before completing the sample, the researchers surveyed the students to answer the questions more confidently. Data were analyzed through descriptive and inferential statistics by SPSS 24 software.

Table 1. Cronbach's alpha coefficient of dimensions of the questionnaire

\begin{tabular}{|c|c|c|c|}
\hline Dimensions & Number of questions & $\begin{array}{l}\text { Cronbach's alpha } \\
\text { coefficient }\end{array}$ & Results \\
\hline Environmental ethics & 5 & $0 / 73$ & Accepted \\
\hline Self-care ethics & 4 & $0 / 78$ & Accepted \\
\hline Family relationship ethics & 4 & $0 / 82$ & Accepted \\
\hline Social ethics & 5 & $0 / 86$ & Accepted \\
\hline Human ethics & 4 & $0 / 81$ & accepted \\
\hline Transcendent ethics & 5 & $0 / 84$ & accepted \\
\hline Total & 27 & $0 / 89$ & accepted \\
\hline
\end{tabular}

According to the above table, the value of Cronbach's alpha of the whole questionnaire is equal to 0.89 and Cronbach's alpha of the dimensions is more than 0.7 , which shows that the reliability of the questionnaire and its dimensions are at the desired level.

\section{Results}

550 questionnaires were distributed among 24 public and non-profit schools for girls and boys, of which 531 completed questionnaires could be analyzed, of which $49.3 \%$ were public schools $(20.9 \%$ boys and $28.4 \%$ girls) and $50.7 \%$ were non-profit (23\% boys and $27.7 \%$ girls).

First, before analyzing the research hypotheses, the Shapiro-Wilk test was used to use the parameter tests to assume the normality of the data, the results of which are shown in Table (2).
Table2. Results of normalizing dimensions of ethics (Shapiro-Wilk test)

\begin{tabular}{|l|l|l|l|} 
Dimensions & \multicolumn{1}{l}{$\begin{array}{l}\text { Shapiro } \\
\text { value }\end{array}$} & \multicolumn{1}{l}{ Sig. } & Results \\
\hline Environmental ethics & $0 / 97$ & $0 / 223$ & Normal \\
\hline Self-care ethics & $0 / 98$ & $0 / 54$ & Normal \\
\hline Family relationship ethics & $0 / 971$ & $0 / 243$ & Normal \\
\hline Social ethics & $0 / 982$ & $0 / 647$ & Normal \\
\hline Human ethics & $0 / 985$ & $0 / 79$ & Normal \\
\hline Transcendent ethics & $0 / 983$ & $0 / 667$ & Normal \\
\hline
\end{tabular}

The findings of Table (2) show that the value of the significance level of the Shapiro-Wilk test is greater than 0.05 , so the null hypothesis is accepted or in other words, the frequency distribution of variables is normal.

Table (3) also presents descriptive indicators (mean and standard deviation of variables). 
Table 3. Descriptive indices of variables by male and female students of public and non-profit schools

\begin{tabular}{|l|l|l|l|l|l|} 
Dimensions of ethics & $\begin{array}{l}\text { Public } \\
\text { boys' school }\end{array}$ & $\begin{array}{l}\text { Non-profit } \\
\text { boys' school }\end{array}$ & $\begin{array}{l}\text { Public } \\
\text { girls' school }\end{array}$ & $\begin{array}{l}\text { Non-profit } \\
\text { girls' school }\end{array}$ & Total average \\
\hline Environmental & $4 / 73$ & $4 / 81$ & $4 / 17$ & $4 / 75$ & $4 / 60$ \\
\hline Human & $4 / 30$ & $4 / 21$ & $3 / 86$ & $4 / 20$ & $4 / 13$ \\
\hline Transcendent & $4 / 15$ & $4 / 15$ & $3 / 79$ & $3 / 96$ & $4 / 00$ \\
\hline Family relationships & $4 / 11$ & $3 / 95$ & $3 / 88$ & $4 / 05$ & $3 / 99$ \\
\hline Social & $4 / 21$ & $4 / 11$ & $3 / 61$ & $4 / 05$ & $3 / 97$ \\
\hline Self-care & $3 / 91$ & $3 / 86$ & $3 / 67$ & $3 / 67$ & $3 / 76$ \\
\hline Total & $4 / 26$ & $4 / 18$ & $3 / 87$ & $4 / 12$ & $4 / 09$ \\
\hline
\end{tabular}

Table 4. Comparison of ethics in public and non-profit schools

\begin{tabular}{|c|c|c|c|c|c|}
\hline Dimensions of ethics & Type of school & Mean & T value & Sig. & Results \\
\hline \multirow[t]{2}{*}{ Environmental } & public & $4 / 45$ & \multirow{2}{*}{$4 / 18$} & \multirow[t]{2}{*}{ 0/001 } & \multirow[t]{2}{*}{ meaningful } \\
\hline & Non-profit & $4 / 78$ & & & \\
\hline \multirow[t]{2}{*}{ Human } & public & $4 / 08$ & \multirow[t]{2}{*}{$2 / 25$} & \multirow[t]{2}{*}{ 0/012 } & \multirow[t]{2}{*}{ meaningful } \\
\hline & Non-profit & $4 / 20$ & & & \\
\hline \multirow[t]{2}{*}{ Transcendent } & public & $3 / 97$ & \multirow[t]{2}{*}{$1 / 56$} & \multirow[t]{2}{*}{$0 / 059$} & \multirow[t]{2}{*}{ meaningless } \\
\hline & Non-profit & $4 / 05$ & & & \\
\hline \multirow[t]{2}{*}{ Family relationships } & public & $3 / 99$ & \multirow[t]{2}{*}{$0 / 45$} & \multirow[t]{2}{*}{$0 / 326$} & \multirow[t]{2}{*}{ meaningless } \\
\hline & Non-profit & 4 & & & \\
\hline \multirow[t]{2}{*}{ Social } & public & $3 / 91$ & \multirow[t]{2}{*}{$2 / 39$} & \multirow[t]{2}{*}{$0 / 008$} & \multirow[t]{2}{*}{ meaningful } \\
\hline & Non-profit & $4 / 08$ & & & \\
\hline \multirow[t]{2}{*}{ Self-care } & public & $3 / 79$ & \multirow[t]{2}{*}{$0 / 58$} & \multirow[t]{2}{*}{$0 / 281$} & \multirow[t]{2}{*}{ meaningless } \\
\hline & Non-profit & $3 / 76$ & & & \\
\hline \multirow[t]{2}{*}{ Total } & public & $4 / 05$ & \multirow[t]{2}{*}{$2 / 15$} & \multirow[t]{2}{*}{$0 / 015$} & \multirow[t]{2}{*}{ meaningful } \\
\hline & Non-profit & $4 / 15$ & & & \\
\hline
\end{tabular}

The findings of Table (3) show that the average of transcendent ethics and self-care ethics are lower than the average of the society. Other dimensions of ethics (environmental, human, family relations and social) are better than the average of the social ethics. The average of total morality in public boys 'schools (4.24) is higher than the average of nonprofit boys (4.18), but the average of total morality in public girls' schools (3.87) is lower than the average of non-profit girls (4.12).

Independent t-test was used to compare the moral status in public and non-profit schools, the results of which are reported separately in each dimension (Table 4).

The results of the independent t-test show that in the dimensions of "environmental", "human" and "social" there is a significant difference between public and non-profit schools at 95\% confidence level and the average morality of non-profit schools is higher than public. But there is no significant difference between public and non-profit schools in terms of the ethical dimensions of "transcendent", "family relationships" and "self-care".

Independent t-test was used to compare ethics in girls' and boys' schools, and the results were reported separately for each dimension.

The results of the independent $t$ test show that there is a significant difference between boys' and girls' schools in the dimensions of "environmental", "human", "transcendent", "social" and "self-care" at the $95 \%$ confidence level. Mean of ethics is more in boys' schools than girls' school. But in terms of "family relationships" there is no difference between boys 'and girls' schools.

Independent t-test was used to compare the moral status in public and non-profit schools for boys, and the results were reported separately by dimensions. 
Table 5. Comparison of ethics in girls' and boys' schools

\begin{tabular}{|c|c|c|c|c|c|}
\hline Dimensions of ethics & Type of school & Mean & $T$ value & Sig. & Results \\
\hline \multirow[t]{2}{*}{ Environmental } & boys & $4 / 77$ & \multirow{2}{*}{$3 / 43$} & \multirow{2}{*}{$0 / 001$} & \multirow{2}{*}{ Meaningful } \\
\hline & girls & $4 / 46$ & & & \\
\hline \multirow[t]{2}{*}{ Human } & boys & $4 / 25$ & \multirow[t]{2}{*}{$2 / 76$} & \multirow[t]{2}{*}{$0 / 003$} & \multirow[t]{2}{*}{ Meaningful } \\
\hline & girls & $4 / 03$ & & & \\
\hline \multirow[t]{2}{*}{ Transcendent } & boys & $4 / 15$ & \multirow[t]{2}{*}{$2 / 98$} & \multirow[t]{2}{*}{$0 / 001$} & \multirow[t]{2}{*}{ Meaningful } \\
\hline & girls & $3 / 87$ & & & \\
\hline \multirow[t]{2}{*}{ Family relationships } & boys & $4 / 03$ & \multirow[t]{2}{*}{$1 / 38$} & \multirow[t]{2}{*}{$0 / 084$} & \multirow[t]{2}{*}{ Meaningless } \\
\hline & girls & $3 / 96$ & & & \\
\hline \multirow[t]{2}{*}{ Social } & boys & $4 / 16$ & \multirow[t]{2}{*}{$3 / 14$} & \multirow[t]{2}{*}{$0 / 001$} & \multirow[t]{2}{*}{ Meaningful } \\
\hline & girls & $3 / 83$ & & & \\
\hline \multirow[t]{2}{*}{ Self-care } & boys & $3 / 88$ & \multirow[t]{2}{*}{$2 / 39$} & \multirow[t]{2}{*}{$0 / 004$} & \multirow[t]{2}{*}{ Meaningful } \\
\hline & girls & $3 / 67$ & & & \\
\hline \multirow[t]{2}{*}{ Total } & boys & $4 / 21$ & \multirow[t]{2}{*}{$2 / 28$} & \multirow[t]{2}{*}{$0 / 011$} & \multirow[t]{2}{*}{ Meaningful } \\
\hline & girls & $3 / 99$ & & & \\
\hline
\end{tabular}

Table 6. Comparison of ethics in public and non-profit boys' schools

\begin{tabular}{|c|c|c|c|c|c|}
\hline Dimensions of ethics & Type of school & Mean & T value & Sig. & Results \\
\hline \multirow[t]{2}{*}{ Environmental } & public & $4 / 73$ & \multirow[t]{2}{*}{$1 / 47$} & \multirow[t]{2}{*}{$0 / 017$} & \multirow{2}{*}{ Meaningless } \\
\hline & Non-profit & $4 / 81$ & & & \\
\hline \multirow[t]{2}{*}{ Human } & public & $4 / 3$ & \multirow[t]{2}{*}{$1 / 54$} & \multirow[t]{2}{*}{$0 / 062$} & \multirow[t]{2}{*}{ Meaningless } \\
\hline & Non-profit & $4 / 21$ & & & \\
\hline \multirow[t]{2}{*}{ Transcendent } & public & $4 / 15$ & \multirow[t]{2}{*}{$0 / 52$} & \multirow[t]{2}{*}{$0 / 170$} & \multirow[t]{2}{*}{ Meaningless } \\
\hline & Non-profit & $4 / 15$ & & & \\
\hline \multirow{2}{*}{ Family relationships } & public & $4 / 11$ & \multirow[t]{2}{*}{$2 / 19$} & \multirow[t]{2}{*}{$0 / 014$} & \multirow[t]{2}{*}{ Meaningful } \\
\hline & Non-profit & $3 / 95$ & & & \\
\hline \multirow[t]{2}{*}{ Social } & public & $4 / 21$ & \multirow[t]{2}{*}{$1 / 91$} & \multirow[t]{2}{*}{$0 / 028$} & \multirow[t]{2}{*}{ Meaningful } \\
\hline & Non-profit & $4 / 11$ & & & \\
\hline \multirow[t]{2}{*}{ Self-care } & public & $3 / 91$ & \multirow[t]{2}{*}{$1 / 37$} & \multirow[t]{2}{*}{$0 / 080$} & \multirow[t]{2}{*}{ Meaningless } \\
\hline & Non-profit & $3 / 86$ & & & \\
\hline \multirow[t]{2}{*}{ Total } & public & $4 / 24$ & \multirow[t]{2}{*}{$1 / 48$} & \multirow[t]{2}{*}{$0 / 069$} & \multirow[t]{2}{*}{ Meaningles: } \\
\hline & Non-profit & $4 / 18$ & & & \\
\hline
\end{tabular}

The results of Table (6) show that in the dimensions of "family relations" and "social" there is a significant difference between public and non-profit boys' schools at the 95\% confidence level and the average morality of boys' public schools is higher than boys' non-profit in these two dimensions. But there is no significant difference between "environmental", "human", "transcendent" and "self-care" dimensions between public and non-profit boys' schools.

Independent t-test was used to compare ethics in public and non-profit girls' schools, and the results were reported separately for each dimension.
The results of independent t-test show that in the dimensions of "environmental", "human", "transcendent", "family relations" and "social", there is a significant difference between public and nonprofit girls' schools at 95\% confidence level. The average of morale of non-profit girls' schools is higher than that of public girls' schools. But in terms of "self-care", there is no difference between public and non-profit girls' schools. 
Table 7. Comparison of ethics in public and non-profit girls' schools

\begin{tabular}{|c|c|c|c|c|c|}
\hline Dimensions of ethics & Type of school & Mean & T value & Sig. & Results \\
\hline \multirow[t]{2}{*}{ Environmental } & public & $4 / 17$ & \multirow[t]{2}{*}{$4 / 36$} & \multirow[t]{2}{*}{$0 / 001$} & \multirow[t]{2}{*}{ Meaningful } \\
\hline & Non-profit & $4 / 75$ & & & \\
\hline \multirow[t]{2}{*}{ Human } & public & $3 / 86$ & \multirow[t]{2}{*}{$4 / 75$} & \multirow[t]{2}{*}{$0 / 001$} & \multirow[t]{2}{*}{ Meaningful } \\
\hline & Non-profit & $4 / 2$ & & & \\
\hline \multirow[t]{2}{*}{ Transcendent } & public & $3 / 79$ & \multirow[t]{2}{*}{$3 / 52$} & \multirow[t]{2}{*}{$0 / 001$} & \multirow[t]{2}{*}{ Meaningful } \\
\hline & Non-profit & $3 / 96$ & & & \\
\hline \multirow[t]{2}{*}{ Family relationships } & public & $3 / 88$ & \multirow[t]{2}{*}{$3 / 36$} & \multirow[t]{2}{*}{$0 / 001$} & \multirow[t]{2}{*}{ Meaningful } \\
\hline & Non-profit & $4 / 05$ & & & \\
\hline \multirow[t]{2}{*}{ Social } & public & $3 / 61$ & \multirow[t]{2}{*}{$3 / 86$} & \multirow[t]{2}{*}{$0 / 001$} & \multirow[t]{2}{*}{ Meaningful } \\
\hline & Non-profit & $4 / 05$ & & & \\
\hline \multirow[t]{2}{*}{ Self-care } & public & $3 / 67$ & \multirow[t]{2}{*}{$0 / 964$} & \multirow[t]{2}{*}{$0 / 172$} & \multirow[t]{2}{*}{ Meaningless } \\
\hline & Non-profit & $3 / 67$ & & & \\
\hline \multirow[t]{2}{*}{ Total } & public & $3 / 87$ & \multirow[t]{2}{*}{$2 / 43$} & \multirow[t]{2}{*}{$0 / 004$} & \multirow[t]{2}{*}{ Meaningful } \\
\hline & Non-profit & $4 / 12$ & & & \\
\hline
\end{tabular}

\section{Discussion}

The purpose of this study was to investigate the moral status of elementary students (second year) in public and non-profit schools in Tehran. The results showed that there is a significant difference between the moral status of public and non-profit schools. In other words, the average morality in non-profit schools is slightly higher $(\mathrm{p}<0.05)$. Other findings indicated that the moral situation in boys' schools was better than in girls'; there was no significant difference between the moral status in public and non-public boys 'schools, but there was a significant difference between public and non-profit girls' schools.

The findings of the present study were consistent with the results of other studies that concluded that there is a significant relationship between students' gender, educational level and moral judgment (20-19). A researcher also showed that there is a correlation between the organizational climate of schools and the moral status (22). Some other researchers also concluded that there is a significant difference between the current situation and the desired situation of educational activities in non-profit schools (23). The researcher concluded that gender has a significant role in semantic and moral orientation (24). Other researchers have concluded that in private schools, the moral development of students is better than in religious (public) schools (25).
In the analysis of the findings, it can be said that non-profit schools have organizational characteristics such as lower student density, tuition and their own rules, to which should be added the attitude and social differentiation of parents. On the one hand, the lower density of non-profit schools provides the basis for better implementation of educational programs and activities in these schools. Teachers also have more opportunities to monitor student activities. On the other hand, the social differentiation of families should be mentioned. Families view nonprofit schools as a kind of social taste and style because the presence of students in nonprofit schools creates a kind of social differentiation for them. Therefore, it can be said that the type of schools in the eyes of families is a kind of social superiority in order to maintain their status distance from others. In this regard, the social learning approach also believes that moral values (like other behaviors) are not formed according to the principles of learning and through reward and punishment or role modeling; rather, the set of behaviors and habits developed by the community is gradually transmitted to the child through learning mechanisms. This theory supports the idea that children derive their moral values from teachers and parents (26). Therefore, the attitude and perspective of parents and teachers in non-profit schools affect the attitude and method of educating students. The results of many 
researches show that the whole school atmosphere is very effective in the moral development of children (11). It can also be said that since nonprofit schools require a relatively high cost for student enrollment, the costs make families more in control of their child's spending and investment. Because they are more likely to interact with the school, these interactions can lead to effective pressure on the operation of nonprofit schools. In such a way that families are sensitive to the smallest appropriate and inappropriate educational behavior of their child and the school is therefore more sensitive to their educational and moral programs. Public schools, on the other hand, face greater student density and greater heterogeneity of parent-student social status. Therefore, these heterogeneities can be a factor for the moral status of students. Because heterogeneities require different moral styles, but in nonprofit schools these heterogeneities are less due to the closer proximity of the parent social level.

Although the results of this study showed that in general, the moral situation (and its various dimensions) is more favorable in non-profit schools than in public schools, but the results of this study face some limitations. The present study was a case study that was conducted in the metropolis of Tehran and in this regard, students from other parts of the country were not studied. Another limitation is the lack of more accurate tools for measuring ethics. Ethics is a relative matter and may have very different perceptions in different parts of the country. Another limitation was the lack of relevant research, which the existence of other studies could help to better adapt to the findings and judgment.

Based on the results, it can be suggested that researchers study other courses in the future to be able to compare public and non-profit schools in higher education. Considering that the vast majority of non-profit primary school students have better economic conditions and parental literacy than public primary school students, it is suggested that in the next research, the relationship between students' ethics and its socio-economic and geographical location should be examined. It is suggested that in public schools, which make up the majority of the country's students, educational and moral programs be held with the participation of families in schools.

\section{Conclusion}

Today, our society more than ever needs ethics in all its dimensions, and its basic foundation is education in the early years of education. Therefore, monitoring the moral status of students requires increasing knowledge of the subject of ethics. The existence of public schools along with non-profit schools is somewhat clear in the quality of education, but in terms of moral development requires several studies that based on the results of the present study can be concluded that the moral situation in non-profit primary schools (second period) is better than public schools. Also, although there is no significant difference between public and non-profit boys 'schools in terms of moral status, it is significant for girls' schools.

\section{Ethical Consideration}

In order to observe research ethics, the purpose of the research was first explained to the students and they were given the option to complete the questionnaires if they wished and it is not mandatory. They were also given the option to rest for a few minutes and then complete the questionnaires if they were tired.

\section{Acknowledgement}

All education departments in different parts of Tehran, as well as dear teachers, principals and students who collaborated in the research are appreciated. Finally, the esteemed professors who presented their valuable suggestions to the researcher are appreciated.

\section{References}

1. Ovcharova R (2020). Research on the moral development of high school students. In: Ecological-socio-economic systems: models of competition and cooperation. Atlantis Press, Paris.
8

Available at: www.ijethics.com 
2. Elias JL (2006). Philosopby of education. Translated by: Zarabi A. Imam Khomeini Education and Research Institute, Qom/Iran. (In Persian).

3. Ikemoto T (2012). Moral education in Japan, Tips for United States' schools. Translated by: Ghaedi Y. School Publications, Tehran/Iran. (In Persian)

4. Sajjadi SM (2000). Moral education in both Postmodernism's and Islam's points of view. Islamic Education Journal, 1(1): 47-90. (In Persian)

5. Abedi Sarvestani A, Shahvali M (2008). The necessities and the properties of researching in environmental morality. Ethics in Science \& Technology, 3 (3 , 4): 56-61. (In Persian)

6. Soltani Renani SM (2013). The components of social morality in both Allameh Tabatabaee's and Shahid Motahari's points of view. Islamic Social Research, 19(1): 3-46 (In Persian).

7. Eslami SH (2008). Gender and ethics of care. Strategic Study of Women, 11 (42): 7-42. (In Persian).

8. Katouzian N (1989). Civil rights (family). Behnashr Publications, Tehran/Iran. (In Persian).

9. Alemzadeh Nouri M (2008). Human being, education, and the psychology of morality. Pegah Publication, Tehran/Iran. P. 239. (In Persian)

10. Khalkhali M, Khalkhali R, Bagherian Jolodar M (2017). The relationship between religious beliefs and moral development and creativity in ninth grade male and female students in district 2 urban planning public schools. Ethical Researches, 8(1): 437.(In Persian)

11. Safder M, Hussain CA (2018). Relationship between moral atmosphere of school and moral development of secondary school students. Bulletin of Education and Research, 40(3): 63-71.

12. Brunello G, Rocco L (2008). Educational standards in non-profit and public schools. The Economic Journal, 1(118): 1866-87.

13. McEwan PJ (2000). The potential impact of large-scale voucher programs. Review of Educational Research, 70(2): 10349.

14. Applebome P, Rancor R (2009). Where non-profit school parents make public-school decisions. Available at: http://www.schoolinfosystem.org/2009/04/27/rancor where pr/.

15. Rafaatjah M (1997). Investigating the effective factors in the academic performance of non-governmental school students. [M.A.Thesis]. Tehran University, Faculty of Social Sciences, Tehran/Iran. (In Persian).

16. Hazeri AM (1994). Non-governmental schools and social mobility. [Ph.D. Thesis]. Tarbiat Moallem University, Tehran/Iran. (In Persian).

17. Sarmad GA (2010). Comparing the management performance in governmental and non-governmental high schools of girls in Tehran. Quarterly of Educational Management Research, 2(6): 97-116. (In Persian)

18. Rafipour F (1998). Development and contradiction. Enteshar Company, Tehran/Iran. (In Persian)

19. Nazari B (2002). The influence of religious attitude on moral judgment and humanism of middle-school and high-school students of Tehran . Unprinted Education Research Project, Tehran University, Tehran/Iran. (In Persian)

20. Parto M (2001). Religious orientation and moral transformation in both middle and high school students. Unprinted Experimental Project, Institute for Education Studies, Tehran/Iran. (In Persian)

21. Hashemi Kari AS (2001). Comparing the growth of moral judgment of street and ordinary children in Tehran (18-7 years old). [M.A. Thesis]. Islamic Azad University, Roodehen Branch, Roodehen/Iran. (In Persian)

22. Ghaderi J (2014). A study of the development of moral judgments of male and female middle school students in Kermanshah. Unprinted Research Project, Tehran University, Tehran/Iran. (In Persian)

23. Jahanian R, Beladinejad H (2015). Study and comparison of the current and desirable situation of non-governmental schools in Karaj from the perspective of students' parents. Educational Leadership and Management Quarterly, 6(2): 25-37. (In Persian).

24. Khosravi Z, Abbaszadeh S (2015). Investigating genderbased interpretive and semantic processes in the selection of moral action. Social Psychological Studies of Women, 13(1): 732. (In Persian).

25. Iqbal S, Khanam A, Dogar AH (2017). A comparative study of moral development of students from non-profit schools and Deeni Madrasah. Journal of Research \& Reflections in Education, 1(11): 113-123.

26. Taghizadeh ME (2013). Ideas and applied and modern methods in education and learning. University of Payame Noor Publications, Tehran/Iran. (In Persian). 